УДК 342.365:342.156:342.514

DOI https:// doi.org/10.32837/yuv.v0i4.1983

\author{
В. Мельник, \\ кандидат политических наук, \\ ассистент кафедры политологии \\ Киевского национального университета имени Тараса Шевченко, \\ преподаватель кафедры философии и общественных наук \\ Винницкого национального медицинского университета имени Н. И. Пирогова, \\ главный редактор журнала «Анналы юридической истории», \\ член Американского общества юридической истории

\section{ЮРИДИЧЕСКАЯ ПРАВОСУБЪЕКТНОСТЬ ТЮРКСКОГО КАГАНАТА (552-568 ГГ.): ИРАНО-ВИЗАНТИЙСКИЙ АСПЕКТ}

\begin{abstract}
Тюркский каганат просуществовал с 552 nо 603 годы, распавшись на два формально единые образования - Западно-тюркский каганат (603-658 гг.) и Восточнотюркский каганат (603-744 гг.) [1, с. 5]. Название народа «тюрки» (в древности - «тюркюты» $[1$, с. 6]) впервые можно встретить в записях китайских историографов, датированных 542 годом. Изначально прототюркские племена, именовавшиеся «Ашина» [1, с. 22-23], занимались промышленной добычей и обработкой железа в предгорьях Алтая. Здесь же они подчинились власти монголоязычного Жужаньского каганата (330555 г2.) [2, с. 32]. В 542 г. ашинские племена объединились с некоторыми алтайскими сородичами и приняли общее название «тюрки». Заметим, что выдающийся востоковед, арабист и тюрковед Василий Бартольд (1869-1930) неоднократно утверждал: понятие «тюрки» необходимо дословно переводить как «люди закона» [3, с. 22].
\end{abstract}

Как и белые гунны-эфталиты, племена Ашина состояли в прямом генетическом родстве с когда-то могущественным племенем хунну и, соответственно, гуннской элитой, управлявшей Поволжьем с 158 г. и правившей Восточной Европой в 376-454 гг. Ашинский вождь Бумын принял титул кагана и в кропопролитной войне 542-551 гг. разгромил соперников-жужаней. Именно Бумын стал основателем суверенного политического образования (вождества), получившего звучное наименование «Вечный Эль Тюркского народа». Племенная аристократия племени Ашинов объединилась при Бумынкагане в единую династию и признала род Бумына достойным править всеми «людьми закона», то есть «тюрками». Таким образом, изначально понятие «тюрки» подразумевало даже не столько этническое родство с подинненными северокитайским жужаням ашиниами, сколько признание власти ашинского правителя. Если племя входило в состав военной орды Бумына, то оно немедленно объявлялось «тюркским».

Около 544 г. тюрки вступили в активные дипломатические отношения с китайскими царями из династии Западная Вэй (535-556 гг.). Характерно, что представители этой «китайской» династии имели сяньбийское происхождение и, соответственно, с легкостью понимали не только политические устремления «Великого Эля Тюркского народа», но и язык алтайских степняков [1, с. 9-10]. В 545 г. состоялась великолепная церемония признания «политических прав тюрок» в вэйской 
столице Чанъань (теперь Сиань). Там китайцы признали название «Вечный Эль Тюркского народа» [4, с. 130] и объявили о своей поддержке ашинским притязаниям на управление всеми племенами Жужаньского каганата. Китайцы послали официальных представителей в степную ставку Бумына на Алтае и заключили союз формального сюзеренитета с «младшими» тюркскими представителями [1, с. 27].

Около 546 г. в состав Великого Эля вошли сибирские племена телеутов. С этого момента тюркское войско начало умножаться в геометрической прогрессии, а каган Бумын постепенно сумел реализовать главную договоренность с вэйскими китайцами - нанёс сокрушительный удар по Жужаньскому каганату [5, с. 181]. В 551 г., после разгрома жужаней, взаимные договорённости вэйцев и ашинцев были подтверждены. Китайцы признали Великий Эль как политически «состоятельное» образование, однако же Бумын-каган в свою очередь признал верховную суверенную власть китайского императора из династии Западная Вэй.

На грани 551 и 552 гг. (предполагаем, учитывая степные алтайские традиции, что это произошло весной 552 г.) Бумын принял новый титул, дарованный ему императорской ставкой Западной Вэй [1, с. 28]. Он стал «ильханом» («правителем народов»), составив костяк орды Великого Эля из ашинцев и телеутов. Впрочем, во второй половине 552 г. Бумын умер, и вся полнота власти перешла к его сыну Кара Иссык Хану.

Хотя сын Бумына, официально признанный «вторым ильханом тюрков» в китайской столице Чанъань, пребывал на «степном троне» менее одного года (552-553), он отличился целенаправленно динамичным государственным строительством. В частности, Кара Иссык Хан сокрушил остатки жужаней, не желавших входить на подчиненных правах в состав
Вечного Эля. Ильханов тюркских народов Кара Исськ Хан впредь повелел называть «Гёктюрк Каганами», то есть «Правителями Небесных Тюрок».

В середине 553 г. орда Кара Иссык Хана Гёктюрка вступила в сражение с ближайшими сородичами жужаней из Маньчжурской степи - аварами [6, с. 143]. Великая тюркско-аварская битва произошла у правого притока Селенги (на р. Орхон, теперь - Монголия). Значительная часть аваров была уничтожена, меньшая вошла в состав Великого Эля на правах жужаней (т. е. на подчинённых правах «младших братьев») [1, с. 28-30]. Еще меньшая часть была вынуждена спасаться бегством маленькими тропами в монгольских горах Букрат. $И x$ переход через реку Орхон в западном направлении стал исходной точкой для нового витка Великого переселения народов и появления аваров на западном берегу Волги в 557 г. [7, с. 92], где новую переселяющуюся азиатскую орду зафиксировали византийские хроники, отмечая дерзость, корыстолюбие и тщеславие аварских вождей [8, Excerpta de Legationibus gentium ad Romanos, 1; 9, Menandr Protector, Fr. 5, 18].

Резюмируем общепринятые характеристики летописных сообщений о дальнейших событиях, имевших знаковое и важное значение для развития восточноримской теории юридической правосубъектности.

Остатки разбитой на Орхоне аварской армии, проделав дальний путь, сумели, однако, оперативно подчинить своей власти (за четыре года!) ираноязычные племена аланов [10] и савиров [11, с. 114] на Северном Кавказе, являвшиеся, в ходе противостояния Византии и Персии за грузинскую Лазику (552-562 гг.), федератами Восточной Римской империи. Параллельно авары подчинили тюркоязычные протобулгарские племена «утригуров» [12, с. 24-25], жившие на Азовском море и ранее 
также получившие lex foedus от императора Юстиниана Великого [13; 14, с. 7-61]. По всей видимости, новоподчиненные аварам византийские федераты (никогда официально не отказывавшиеся от такого правового статуса) рассказали аварской знати о «несметных сокровищах Константинополя» [15, р. 194]. С этим и связано требование их первого посольства, прибывшего с Волги в Константинополь в конце 557 г., «бояться аваров как самого могущественного племени Скифии и предоставить им драгоценности и земли в пределах империи для поселения» [16, Agath. Hist. V, 10; 17, Theoph. Chron. A. M. 6050]. Такое противоречивое требование Юстиниану лично высказали посланцы аварского кагана Баяна, участвовавшие в дворцовых мероприятиях в течение января-февраля 558 г. Юстиниан снабдил послов большими подарками для кагана Баяна и всей аварской знати, а также охраной, ведшей послов «через Скифию» вплоть до начала донско-волжских кочевий аварских воинов [1, с. 36]. В итоге Баян принял предложение императора - получил lex foedus [18, с. 195] на Волго-Донское междуречье и провозгласил аварский союз племен официальными федератами Восточной Римской империи [9, Menandr Protector, Fr. 5, 9, 14; 19, Theophyl. Simoc., III. 6.11, 14; 20]. Как и в случае с правлением Теодориха Великого (493-526) или Хлодвига (481-511), каган Баян получал от Юстиниана признание его «наместником Скифии» и заверение в защите со стороны императорского войска от потенциальных притязаний ашинцев-тюрок [21, с. 359-363].

Необходимо понимать, что хорошо осведомленный Юстиниан знал о слабости аварской элиты (не только благодаря шпионам из Персии, но, главным образом, благодаря хорошо налаженной поставке информации в черноморском бассейне и на прилегающем к нему Северном Кавказе).
Аварская элита была мала числом и выигрывала только умением объединять вокруг себя чтивших военную доблесть тюрок и номадов-иранцев, кочевавших вдоль течения великих восточноевропейских рек (Волга, Дон, Днепр, Южный Буг). Собственно, только это умение Юстиниан и оценил. Император, носивший титул «победителя антов» ${ }^{1}$ [22, с. 195], стремился $\kappa$ полному объединению Скифии под своей властью и рассматривал территорию от Дуная до Волги в качестве северной границь Византии [23, с. 59-92]. Приход жужаньских аваров не срывал Юстиниану политическую игру, а наоборот, её укреплял [другая точка зрения: 21, с. 362]. Не надо было посылать никаких войск или специально обученных стратигов в Тирас, Ольвию, Херсонес или Боспор. Объединение «скифских» кочевых племён (совершенно разнородных и полиэтничных, с мощными вкраплениями славянской, германской, иранской, гуннской крови) в единое политическое образование, подконтрольное официальному Константинополю, теперь должно было осуществиться аварскими руками.

Итак, военно-политический старт Аварскому каганату (типичному кочевническому вождеству по своей внутренней юридической структуре [о «вождестве» 24, с. 29; 25, pp. 164-169; 26 , с. 8-10; 27]), просуществовавшему в Европе согласно правовой санкции Юстиниана Великого с 558 по 805 годы, дала экспансия Кара Иссык Хана Гёктюрка в пределах современной Монголии. К слову, именно родной дядя Иссык Хана по имени Муган-каган в дальнейшем возглавил Вечный Эль Тюркского народа (с 553 г.) [1, с. 28], став, пожалуй, самым выдающимся тюркским ильханом («Гёктюрк-каганом»).

1 Полный титул Юстиниана: «Император Цезарь Флавий Юстиниан владыка Алеманнский, Готский, Франкский, Германский, Антский, Аланский, Вандальский, Африканский» [22, с. 195]. 
Первоначальные действия Муганкагана (553-572) в монгольской степи были связаны с необходимостью «добить» верные жужаньскому правлению племена, объединившиеся с некоторыми жужаньскими вождями и активно пытавшиеся восстановить Жужаньский каганат в пределах новообразованного Вечного Тюркского Эля $[28$, с. 31$]$.

Cлавные воины-жужани, поддержанные некоторыми остатками монгольских аваров, сумели привлечь к своему восстанию китайское государство Северная Ци во главе с «изицзином» Вэнь Сюань-Ди ГаоЯном (годы правления: 529-559). Вышло так, что Западная Вэй поддержала Тюркский Эль, а Северная Ци выступила на стороне жужаней. Таким образом, тюрки органично вошли в сферу междоусобных войн, отравлявших китайскую жизнь в течение всего VI-го века [1, с. 30-32]. Каждая из феодализирующихся китайских политий, провозглашая себя единственной китайской империей, пыталась создать ударный отряд в лице собственной вассальной орды монгольских степняков [28, с. 36-39]. В частности, Северная Ци отказалась признать Тюркский Эль и называла его территории и племена жужаньскими. Муган-кагану, в самом начале правления, было даже нанесено китайцами сокрушительное поражение у границ владений Северной Ци.

Противостояние вэйско-тюркского и ци-жужаньского союзов длилось целых два года. B 555 г. Западная Вэй одержала верх. Остатки жужаней, с вассально зависимыми аварскими семьями, были изгнаны из Северной Ци и пленены вәйской армией. В 556 г. вэйщы передали пленников Муган-кагану, организовавщему казнь трёх тысяч мужчин u распределившему жужаньских женщин между своими приближенными. Так окончилась жужаньская история [28, с. 34], а жизнь аварских беженцев оказалась навсегда связанной с Центрально-Восточной Европой.

Родной дядя Муган-кагана Истеми-каган был назначен командующим «западной Ордой Тюркского Эля», куда вошли многие западноалтайские племена. Именно эта часть тюркской орды нанесла ряд сокрушительных поражений белым гуннам-эфталитам и начала тюркскую экспансию в пределах ираноцентричной Средней Азии [1, с. 33].

Еще в 554 г. персидский шахиншах Хосров Ануширван (531-579) отправил посольство с богатыми подарками в кочевья Муган-кагана и предложил Великому Элю мирный договор на достаточно заманчивых условиях [29, с. 585]. Тюрки должны были помочь Хосрову разгромить эфталитов, за что «царь царей» обещал им поселение вдоль всей восточной границы Ирана, извечное денежное содержание и государственные посты. Фактически «тюркский ход» Хосрова $(554$ г.) можно анализировать, сравнивая с ответом Юстиниана аварскому посольству четьрью годами позже (558 г.). Оба «царя царей» жаждали приобщить большие степные конгломераты народов (в первом случае тюрок, во втором случае - аваров) к делу государственного обустройства и реформирования собственных империй. Хосров Ануширван хотел, наконец, разрешить эфталитскую проблему и не видел способа лучше, чем «выбить клин клином». Само персидское войско было ослаблено постоянными войнами «на два фронта» (с Восточной Римской империей на западе, с эфталитами на востоке) и не могло окончательно уничтожить своих противников ни на одном направлении. Персы нуждались в помощи тюрок, также как и тюрки нуждались в персидском покровительстве для своего цивилизационного развития и территориальной экспансии.

Юстиниан Великий также пытался «лечить подобное подобным». Тюрко- 
язычные аварские элиты, признанные в савирской, булгарской и алано-осетинской федератской среде благодаря собственному мужеству в противостоянии Тюркскому Элю, представлялись императору Юстиниану реальной возможностью сплотить всех кочевников Северного Причерноморья, подчинив их, наконец, единой политической воле Константинополя, посредством устройства единого административно-территориального центра власти [у Л.Н. Гумилева другая точка зрения: 1 , с. 39].

Получив в 558 г. lex foedus на владение поволжскими и донскими степями, каган Баян обязывался по первому требованию выставлять войска для помощи Юстиниану, а также должен был проводить военные операции в центральных и западноевропейских странах под руководством византийских стратегов. Схема была близкой $\kappa$ персидско-тюркской модели взаимоотношений: Юстиниан финансировал, Баян воевал. Впрочем, сами авары тоже сознавали все слабые стороны византийской внешней политики, поскольку изначально пытались «устрашить» Юстиниана. Восточноримская армия, как и персидское войско, устала от постоянной необходимости противостоять врагам на двух фронтах. С одной стороны, Восточная Римская империя тратила огромные средства на содержание своих контингентов по всему североафриканскому побережью, в Италии, Провансе, Испании. Кстати, в отличие от Хосрова Ануширвана, Юстиниан Великий вдесятеро больше денег тратил на свой военно-морской и торговый флот (средиземноморскую коммуникацию), а также был вынужден постоянно перестраивать громадное количество крепостей (взять хоть бы даже Дару возле месопотамского Нисибиса). С другой стороны, перманентное состояние войны на ирано-византийской границе не добавляло лишних золотых солидов имперской казне Византии. Вот почему Юсти- ниан должен был не пренебрегать аварами, но радоваться их желанию «вступить» в имперское сообщество. Византийцы и авары поняли друг друга. Следовательно, уже в 558 г. авары стали частью восточноримского политического пространства, признав высшую власть Юстиниана.

Хосров Ануширван, однако, добился аналогичного статуса «сюзерена» степной орды на четыре года раньше Юстиниана Великого. Договор между Тюркским Элем и Эраншахром был скреплен взаимными клятвами на Aлтае в марте 554 г. Дочь Истеми (родного дяди Муганкагана) была отдана в жёны Хосрову Ануширвану и должна была стать его «главной женой» [29, с. 586]. В ответ Муган-каган признавал верховную власть шахиншаха над Тюркским Элем и передавал ему «для военной нуждь» всю западную орду под командованием теперь уже официального шахиншахского тестя Истеми-кагана.

Отметим, что отправка Истеми «на подмогу» Эраншахру многими на Алтае воспринималась как почетная ссылка в памирские горы и как попытка Муган-кагана избавиться от угрожающего его власти родственника. Муган продолжал активно сотрудничать с китайцами, участвуя в их междоусобных конфликтах и выжимая с локальных «императоров» значительные подарки. В свою очередь Истеми-каган очень быстро достиг небывалых для тюрок-ашинцев результатов. Эфталиты терпели поражение за поражением, даже без помощи измождённых византийскими войнами иранских контингентов. В коние 554 г. все сынизянские племена, семиреченские кочевья, Хотан u почти весь Хорезмийский оазис признали верховную власть Вечного Эля Тюркского народа [1, с. 34]. В марте 555 г. Истеми-каган вышел на берега Аральского моря, а к январю 557 г. передовые тюркские отряды появились на левом берегу Волги 
[1, с. 35]. Именно это галопирующее приближение тюрок-ашинцев вынудило в 557 году аварского кагана Баяна срочно искать союза с Юстинианом Великим [1, с. $36 ; 30$, с. 8-9]. Впрочем, и Константинополь, и авары с новоподчинёнными им булгарами, аланами и савирами понимали, что без подхода основной орды, находившейся в Алтайской степи, тюрки никогда не начнут форсировать Волгу и открыто вторгаться в де-юре византийскую Восточную Европу, предпочитая предварительно упрочить своё политическое влияние в пределах только что завоёванных оазисов Средней Азии.

Вся территория современного Казахстана, начиная от установившейся теперь китайско-казахской границы, значительная часть современных Узбекистана и Туркменистана, с Бухарой и Самаркандом включительно, а также вся Сынцзян-Уйгурская автономия нынешнего Китая, большая часть долин таджикского и афганского нагорий, благодаря действиям полководца Истеми стали владениями Тюркского каганата. Убийство тюркского посольства эфталитами (560 г.) привело к окончательному разгрому белых гуннов-эфталитов тюрками на территории современной Кашкадарьинской области Узбекистана (в 565-м году). Главная битва возле крепости Карша продолжалась целых восемь дней и окончилась грандиозной победой шахиншахского тестя Истеми [1, с. 40]. В середине 565-го года даже существовала реальная угроза полной оккупации тюрками Хорасана. В итоге Хосров Ануширван, окончив войну с Восточной Римской империей, поспешил к восточным границам и восстановил персидский контроль над ранее подвластной эфталитам Бактрией. Граница между Новоперсидским царством и Вечным Тюркским Элем прошла вдоль реки Амударьи [29, с. 587-588]. Муган-каган вновь подтвердил верховную власть Хосрова, продол- жая, однако, ежегодно признавать также сюзеренитет китайских властителей. Установив наконец дружеские отношения с Истеми-каганом и признав его вторым человеком в Тюркском Эле, Муган пытался лавировать между Ираном и Китаем, получая наибольшие выгоды на обоих направлениях. Грабить и жечь близлежащие области Муган запретил всем своим багадурам (то есть «богатырям» [1, с. 34] - военачальникам, «генералам» или «комитам» на римский манер). Получив контроль благодаря примирению с Истеми-каганом над территориями вплоть до берегов восточного побережья Каспийского моря и астраханской дельты Волги [29, с. 586-587], алтайский Гёктюрк-каган закономерно увидел возможность создания крепкого и политически самостоятельного государства вокруг Великого Шелкового пути. Соответственно, уничтожать Китай не входило в интересы кочевников. Тюрки желали продолжения дружеских, а когда было необходимо, то и вассальных отношений с китайцами ради получения монополии на провоз через свои территории китайского шелка и великого множества иных товаров. Все ключевые оазисы этой величайшей международной торговой дороги после официального договора между Муган-каганом и Хосровом Ануширваном о разделе эфталитских владений (566-й год) находились под прямым контролем Вечного Тюркского Эля [1, с. 41-43].

Крупнейшие городские центры Хорезма еще десятилетием ранее признали власть Истеми и Мугана. Договор же Мугана и Хосрова от 566 г. предусматривал юридическое признание Эраншахром права тюрок на приобретённые в Средней Азии земли [29, с. 587-589]. Получив такую юридическую «индульгенцию», тюрки не стали ждать и обратились к феодальным китайским правительствам с просьбой присылать караваны 
товаров и не бояться грабителей или войн, поскольку тюркская орда обязалась охранять каждого купца. Муган-каган ввёл в действие закон о неприкосновенности всех торговцев в пределах Вечного Тюркского Эля. Все же товарь, происходившие из Китая и пересекавшие владения тюркского Гёктюрк-кагана в любом направлении, признавались на время их пребывания в границах Эля личной собственностью кагана тюрков. Тронуть товары означало оскорбить кагана и быть убитым. Тюрки активно занимались восстановлением коммуникаций и инфраструктуры вдоль древнего Великого Шелкового пути [31, с. 542] $]^{2}$, нарушенных ранее эфталитскими набегами. Основные опорные пункты для складирования товаров и отдыха китайских купцов были воссозданы в Согдиане - иранской провинции, ранее занимаемой эфталитами, но после договора 566 г. переданной Эраншахром в пользование Тюркскому Элю [32, с. 27-35].

Надо заметить, что вместе с активной внешней политикой вдоль Великого Шелкового пути, соединявшей Китай и Иран, тюрки в течение 550-560-х гг. осуществили ряд завоевательных походов на севере и востоке - в сибирском и дальневосточном направлениях. Пока Истеми-каган пугал аваров своими успехами в Прикаспийском регионе и даже дошел до берегов Волги (557-й год), сам верховный правитель Вечного Тюркского Эля Муган-каган в 554 г. лично подчинил все племена к югу от Саянских гор - чиков и киргизов. В 555 г. Муган-каган завоевал кочевья татаров, отуз-татар и воинственных дальневосточных киданей, а в 556 г., по заданию правительства Западной Вэй, покорил тогонские владения сяньбийцев. Восточной гра-

\footnotetext{
${ }^{2}$ Шарль Диль отмечал, что Великий Шелковый путь занимал около 230 дней. От Желтого моря до Персии караваны двигались 150 дней, а от восточноперсидской границы до пограничной дороги Нисибис-Дара надо было идти еще 80 дней [31, с. 542].
}

ницей Тюркского Эля, таким образом, стало побережье Желтого моря.

В 563 г. тюрки успешно участвовали в очередной гражданской войне в раздробленном Китае. Таким образом, Муган-каган, хотя и не командовал лично войсками во время западной кампании Истеми против эфталитов, однако параллельно сумел завоевать непререкаемый авторитет в среде воинов благодаря военным и экономическим успехам, значительным территориальным приобретениям и уважению, которое ему заслуженно оказывали почти все правители раздробленных китайских «империй». Для многих китайских удельных князьков Муган являлся единственной гарантией спокойного существования, и многие китайцы, а также корейцы и приморские народы Дальнего Востока соревновались между собой, предлагая кагану свою вассальную службу. Bот почему $\kappa$ моменту заключения Договора о разделе эфталитского наследия между персами и тюрками (566-й год) Муган-каган был окончательно признан дядей Истеми верховным лидером Евразийской степи, а все их внутриродовые раздорь ушли в прошлое. Постепенно Муган предпринял ряд шагов к централизации подвластных территорий. Защита караванов вдоль Великого Шелкового пути требовала от тюрок решительности во внутриполитической организации собственного вождества [1, с. 57].

Здесь мы вплотную подходим к важному историко-юридическому вопросу: уже в 562, 563, 565 и 566 га. тюркские посль, помимо устоявшихся дружеских связей с Эраншахром, открыто контактировали c Восточной Римской империей. Юстиниан Великий (527-565) и его племянник-преемник Юстин II (565578) позволили Вечному Тюркскому Элю организовать администрирование поставок китайских товаров в пределы византийских владений. Основная внешнеполитическая 
дискуссия, очевидно, ила только вокруг образования Константинополем Аварского каганата [1, с. 48]. $\mathrm{K}$ тому времени это политическое объединение являлось союзом византийских федератов и смогло взять под контроль большие пространства к востоку от дельты Днепра. Тюркский каганат просил императора отказаться от покровительства аварам и называл их «псевдоаварами», недостойными имени тех, кто погиб от тюркских мечей еще в Северном Китае и Монголии.

Пока Юстиниан Великий был жив, он рьяно отстаивал интересь подчинённых ему аваров, передав им lex foedus на владение землями антов (славян) как на левом берегу, так и в правобережье реки Днепр (это случилось около 560-го года). В результате постепенно авары изменили этнокультурную и религиозно-политическую окраску, естественным образом смешиваясь с иранскими племенами Приазовья, протобулгарами Поволжья и славянами (антами) Поднепровья. Заметим, что к 600-му году от настоящих маньчжурско-монгольских аваров в пределах Восточной Европы остались только жалкие следы в среде политической верхушки Аварского каганата. В 560-е гг. процесс смешивания кочевников и земледельцев на приднепровских территориях шел полным ходом. Вначале в этом процессе доминировала сила и динамика кочевников, но очень скоро, не без воздействия страха перед тюркской угрозой из Вечного Эля, аварские политические капли растворились в славянском этническом море. Следовательно, процесс славянизации Аварского каганата, изначально запрограмированный мудрой административной политикой Юстиниана Великого, необходимо признать главной чертой культурного развития Восточной и Центральной Европы в течение следующего VII-го века [33, с. 203-204].
Однако 14 ноября 565 г. управление Юстиниана наследовал племянник Юстин II (565-578). Он отнёсся к просьбам тюрок намного либеральнее. В константинопольском дворце начали обсуждать возможность передачи Тюркскому каганату пространств между Доном и Волгой. Стоит здесь опять отметить, что тюрки так же легко признали сначала Юстиниана, а потом и Юстина II «верховными владьками мира», как это было и в случае Хосрова Ануширвана или китайских императоров Западной Вэй. То есть император Юстин II с правовой точки зрения не подразумевал отчуждения византийских владений Восточной Европы в пользу какого-то другого государства. Формально об этом не могло идти и речи. Тюрки ведь сами называли себя «вассалами небесного императора Нового Рима». Этот факт, равно как и стягивание Муган-каганом тюркской орды к левому берегу Волги, заставили Аварский каганат принять собственное решение о всеобщем переселении подданных им кочевников на правый берег Днепра.

Муган-каган объяснял подданным, что освоение Восточноевропейской равнины, составной части Великой Евразийской степи, жизненно необходимо тюркам на случай противодействия функционированию Великого Шелкового пути со стороны Сасанидского Ирана (на случай противодействия шахиншаха обогащению Вечного Тюркского Эля). Разлад в изначально дружеских отношениях династий Сасанидов и Ашина наступил очень скоро [29, с. 590592]. Зачатки агрессивного восприятия экономической экспансии тюрок были продемонстрированы Хосровом Ануширваном сразу после дружественного Договора о разделе эфталитского наследия 566 года [34, с. 187]. Таможенные пункты сасанидской Бактрии и Хорасана начали препятствовать прохождению китайских и согдийских караванов вглубь 
Персии [29, с. 591], также участились грабежи торговцев шёлком в южном Прикаспии.

Для преодоления закономерного возмущения Хосрова Ануширвана тюркским обогащением Муган-каган снарядил большое купеческое посольство, состоявшее из хорезмийцев и согдийцев. Его возглавил Маниах Согдийский [1, с. 44]. В 567 2. посольство прибыло в Ктесифон и, используя влияние купцов-несториан из местного патриархата, добилось аудиенции шахиншаха. Итог дипломатической борьбы за перераспределение материальных благ был предсказуем: цзарь цзарей купил весь шёлк, привезенный купцуами из Тюркского Эля в Эраншахр, и сжёг его на виду изумленной столичной толпь [34, с. 209]. Хосров Ануширван объявил, что все шёлковые и любые другие караваны, входящие с территории Китая на древние земли персов, «принадлежавшие ещё Ахеменидам», должны обращаться за помощью и, соответственно, платить таможенные сборы не его вассалам тюркам, а официальному Ктесифону [контекст: 29, с. 590-592]. Этим высказыванием Хосров заявил, ито считает почти треть территории Тюркского Эля «своей по историческому праву». Сами же тюрки, по убеждению шахиншаха, согласно Договору 566 г. лишь получили право военного поселения и подчинения шахиншаху на землях, продолжавших де-юре оставаться его личным владением. Таким образом, таможенный контроль, отдых, перегрузка и формирование караванов с китайскими товарами, а также вся торговля и доходы в Хорезме и Согдиане, должны были контролироваться и финансово сопровождаться ктесифонскими, а не алтайскими администраторами [35, с. 202-204].

Мудрая реакция Муган-кагана на ктесифонское происшествие сдержала гнев тюркских багадуров. В 568 г. каган лично сформировал второе посольство, состоявшее теперь из тюрок (воинов), а не согдийцев или хорезмийцев (купцов). Послы Мугана снова просили шахиншаха позволить им переправлять караваны и считать это царской милостью для подданных. Их внезапная смерть в Ктесифоне выглядела очень странно, и многие тюрки поспешили объявить своих послов отравленными Ануширваном [1, с. 45]. Сейчас тяжело расследовать эти события, но разве Хосров не мог уничтожить таким же образом и первое посольство тюрок? Кроме того, шахиншах, если бы желал войны, то убил бы послов «официально» открыто и не таясь. Следовательно, предположение, что послы умерли своей смертью, имеет право на существование ( $к$ примеру, от очередной эпидемии, ибо вспьики бубонной чумы после юстинианового пика 542-544 г2. теперь были постоянным «сезонным» явлением в жизни всей Евразии). Но такое предположение не единственное. Учитывая политический талант Муган-кагана, на наш взгляд, не будет преувеличением утверждать, что тюркский лидер был способен тайно умертвить нескольких собственных агентов для создания законного повода к войне. Если принять такую версию, то останется только один вопрос - идеологический. Почему позиция Гёктюрк-кагана настолько существенно изменилась в сравнении с предыдущим 567-м годом?

Летом 567 г., тогда же когда Маниах Согдийский убеждал Хосрова Ануширвана признать право Тюркского Эля на администрирование Великого Шелкового пути, западнотюркская орда Истеми-кагана получила приказ Муган-кагана о вторжении в Восточную Европу (форсирование Волги). Сам же Муган-каган заручился поддержкой императора Юстина II [1, с. 46]. Такой шаг призван был создать возможность альтернативного персидскому северного направления на Великом Шелковом пути. Оккупация восточно- 
европейской равнины и получение lex foedus от восточноримского императора позволяли Истеми и Мугану создать новую сетку торговых факторий для перегрузки товаров и отдыха караванов. Эти фактории, по замыслу Муган-кагана, должны были обойти Каспийское море не с юга, как это было много столетий подряд, а с севера - через казахские и астраханские степи. Далее, поскольку на Кавказе постоянно шли византийско-персидские стычки, альтернативный торговый путь должен был пересечь Волгу и двигаться вдоль течения Дона. Приазовье считалось тюрками достаточно безопасной гаванью для потенциального создания морских портов на месте когда-то процветавших древнегреческих колоний. Вся азовская акватория, контролируемая де-факто тюрками, должна была де-юре оставаться восточноримской провинцией. То же касалось и Крыма, где мощные византийские крепости не позволяли надеяться степнякам-тюркам на ито-то иное, кроме покровительства Византии.

Крепости Крыма и всего Северного Причерноморья тюрки планировали использовать как перевалочные центры согласно своим далекоидущим торговым замыслам [36, с. 127-129]. Из Приазовья и Крыма караваны Великого Шелкового пути, включая не только китайские, но и согдианские, мервские и хорезмийские товары, способны были перемещаться как по Черному морю (кораблями), так и по суше - от Ольвии до Константинополя. Вот почему возможность контролировать Волгу и Приазовье считалась тюрками недостаточной. По всей видимости, Юстин II, соглашаясь с доводами послов Мугана [34, с. 24], позволил тюркам занять все причерноморские степи, вплоть до дельты Днепра и даже вплоть до нижнего течения Южного Буга [1, с. 48]. Это объясняет полностью позитивное восприятие восточными римлянами, осо- бенно ольвиополитами и крымчанами, стягивания западнотюркской орды к берегам Днепра, произошедшего в 567-568 гг. Итак, если юго-западная граница Тюркского Эля установилась вдоль северокавказской горной цепи, то крайняя западная граница каганата достигла Днепра в районах современных Запорожской, Днепропетровской и Херсонской областей Украины.

Основной ударной силой новоявленной западнотюркской орды Истеми-кагана стали племена огузов (позднейших печенегов, предков современных туркменов). Именно огузы сокрушили остатки аваров, не успевшие переселиться на запад. Теперь же аварам пришлось спешно отступать даже западнее Южного Буга. Основная часть аварской орды, оставив небольшой заслон в Буго-Днестровском междуречье, совершила стремительную атаку на королевство гепидов в западной части Дакии. Илператор Юстин признал этот поход правомерным из-за постоянных бунтов гепидских рексов. Его распоряжением древняя Дакия в коние 567 г. была официально передана Аварскому каганату как зависимому от Восточной Римской империи политическому образованию [фон событий: 20; 38].

Рядом с Дакией находились паннонийские владения лангобардов, получивших lex foedus от Юстиниана Великого. Лангобарды как «союзники авар», по мнению Юстина II, должны были присматривать за их благонадежностью с запада. Признав в очередной раз суверенитет восточноримского императора (567 г.), каган Баян, в содружестве с подчинёнными буго-днепровскими славянами, осуществил резню гепидов. Однако, получив новости, что тюркская орда Истеми разгромила аварский заслон на Южном Буге и покорила тамошние славянские племена (возможно, тюрки сомкнулись с восточноримскими мезийскими отрядами в между- 
речье Прута и Днестра), каган Баян нарушил навязанный Юстином II союз с лангобардами и вторгся в пределы их королевства в Западной Паннонии.

Впрочем, лангобарды, напуганные славяно-аварскими жестокостями в Гепидии, заранее приготовились к бегству на запад. Сложилась интересная культурно-политическая ситуация, когда миграционные процессы Великого переселения народов порождались страхом и бегством с востока на запад. Таким образом, авары убегали от тюрок, завоёвывая все новые и новые земли в Европе (в частности, гепидскую Дакию и лангобардскую Паннонию). Лангобарды предусмотрели такой поворот событий. Большая часть лангобардов тоже смогла убежать на запад, не дожидаясь открытого аварского вторжения в паннонийские степи. Убегая от аваров, в 568 г. лангобарды начали вторжение в восточноримскую Италию. В течение 568-572 г2. они сумели разгромить несколько византийских отрядов и завоевать треть Апеннинского полуострова [18, с. 197]. Началась новая эпоха в жизни этой страны, приведшая в итоге к усилению власти Римского Папства над Италией и к политическому ослаблению византийских институтов Западной Европь.

Авары в свою очередь не стали вторгаться в Италию, бывшую, в отличие от завоеванных вождеств германских федератов, «личной собственностьюимператоров». Онидовольствовались разграблением богатых федератских королевств гепидов Дакии и лангобардов Паннонии. Оставшиеся в живых гепиды и лангобарды были порабощены, а на их место авары привели с собой славянскую пехоту - авангард аварского войска. Вытеснив лангобардов в Северную Италию, где варвары вступили в противостояние с византийскими войсками и сумели оккупировать несколько крупных внутрен- них районов (без доступа к морю), авары предприняли массовое заселение паннонийской степи и западной Дакии подконтрольными им славянскими выходцами из Буго-Днепровского междуречья. Именно по инициативе и под политическим контролем Баяна I была осуществлена первая в истории массовая колонизация отдельной римской провинции славянами-антами. Смешиваясь с остатками германцев и римлян, славяне меняли свой внешний этноантропологический облик, принесённый из Поднепровья, но, впрочем, не изменили внутреннего этнокультурного естества. Политическое содержание Аварского каганата постепенно становилось славянским.

Итак, в конце 560-х гг. азиатские кочевники взяли под военно-политический контроль большую часть Восточной и Центральной Европы. Почти вся Восточноевропейская равнина, известная в римской картографии как Сарматия или Великая Скифия, вошла в состав Тюркского каганата. В то же время огромная территория между Южным Бугом (на востоке), Вислой (на севере), Одером (на западе) и Дунаем (на юге) стала известна современникам как «Аварский каганат» - политическое образование, regnum foederati, представлявшее федеративный союз кочевников тюрко-монгольского и иранского происхождения (с одной стороны) со славянами-земледельцами (с другой стороны). И Тюркский, и Аварский каганаты де-юре признавали высшую власть императора Восточной Римской империи.

Поскольку летом 567 г. западнотюркская орда Истеми-кагана вошла в степи Северного Причерноморья и вышла на границы с военными заставами Восточной Римской империи, Муган-каган (553-572) принял решение заключить военный союз с официальным Константинополем и объявить войну Эраншахру. Полученный Истеми-каганом lех 
foedus om Юстина II (565-578) означал, что Вечный Тюркский Эль вошёл в юридическую конструкциню Восточной Римской империи и стал составной частью римского публично-правового поляз. Теперь официальный Константинополь нёс ответственность перед новыми федератами и обязан был помочь тюркам военными контингентами в случае начала очередной большой войны.

В 568 г. император Юстин II снарядил посольство во главе с Земархом Киликийским [29, с. 590-592], которое должно было встретиться с Муган-каганом в районе среднего течения Сырдарьи. Это посольство, полностью загруженное подарками и дарственными письмами, прошло галопом всё Северное Причерноморье. Очевидно, что около древней Ольвии Земарха Киликийского встретили охранные отряды Истеми-кагана. Они помогли посольству форсировать Днепр и Волгу, сопровождали Земарха через астраханские и оренбургские степи, прошли большую часть современного Казахстана. Прежде чем Земарх встретился с Истеми-каганом, он вместе со всеми сопровождающими прошел особый тюркский обряд очищения между двумя большими кострами. Обсудив главные предложения Юстина с Истеми, Земарх был допущен в «главную юрту» Тюркского Эля [30, с. 10-13].

Очень жаль, что мы крайне мало знаем об этих первых концептуальных переговорах между Византией и Тюркским каганатом. Из сообщений хронистов известно, что Земарха Киликийского поразили чистота и богатое убранство «главной юрты». Также известно, что Муган-каган через Истеми подтвердил все существовавшие ранее договоренности между официальным Константинополем и тюрками, включая ста-

\footnotetext{
3 Форма принесения присяги на верность Юстину II тюркскими послами под руководством Маниаха Согдийского четко соответствует присягам других федератов Восточной Римской империи $[37$, с. 28$]$.
}

тус федератов, полученный западным ответвлением тюркской орды под командованием Истеми-кагана [30, с. 12]. Но разве только за этим могло идти специальное посольство византийского правительства? Разве не достаточно было организовать переговоры двух посольств на Днепре или Волге? Зачем Юстин подвергал опасности своих легатов и отправлял их в такую даль?

Мы не будем искать ответов в традиционно обсуждающемся и зачем-то осуждающемся безумии императора Юстина II (565-578). Ведь в 567-568 гг. Юстин был все еще подающим надежды «новым» императором и не проявлял никаких признаков грядущего психического расстройства, окончательно погубившего его политику в следующем десятилетии. В 567 году Юстин пытался продолжать политику великого дяди, и ничего не могло помочь больше получения вассальной присяги от самого мощного политического объединения кочевников Евразии. Именно Юстин позволил тюркам завоевать пространства между Волгой и Южным Бугом [9, Menander Protector, Fr. 14]. Именно Юстин предоставил Истеми-кагану статус федерата и не возражал против силового вытеснения на запад других подчинённых Византии федератов (аваров). По всей видимости, мягкая первоначальная реакиия Восточной Римской империи на вынужденное вторжение лангобардов в Италию (568572 ге.), спровоцированное именно аварским завоеванием паннонийских лангобардских владений и геноцидом гепидов со стороны славяноаваров, также обозначала меньшую значимость итальянских событий в сравнении с причерноморскими или даже среднеазиатскими. Всё внимание Юстина было обращено не к аварам, их войнам с гепидами или лангобардами, не к лангобардским перемещениям в сельские районы 
Италии, а к тюркам. Думается, что это было не случайным помутнением разума, а хорошо спланированной геополитической стратегией.

Как мы уже увидели, Юстиниан Великий отдавал много сил и энергии любым контактам и дипломатическим возможностям, открывавшимся восточноримской внешней политике бескрайними степными просторами Средней Азии [39, с. 234-235]. Впрочем, для окончательной инкорпорации Тюркского Эля в состав юридического пространства Восточной Римской империи византийцы должны были получить гарантию пожизненного культурного единства - крещение тюрок. И такое крещение должно было отдать новые среднеазиатские епархии в подчинение Константинопольского патриархата, усиливая канонические институты, легализованные V Вселенским Константинопольским Собором (553 г.) [40, с. 462-481].

Антиохийский патриархат в 541 г. получил такой удар со стороны войск Хосрова Ануширвана, что вплоть до конца VI в. не мог оправиться [39, с. 253]. Александрийский патриархат постоянно строил заговоры и был разделен на две церкви, среди которых лишь монофизитская, следовательно незаконная, обладала абсолютной поддержкой коренных египтян. Иерусалимский патриархат являлся крайне слабой церковью, страдающей одинаково сильно от притеснений со стороны общин сирийских несториан, египетских монофизитов и евреев иудейского вероисповедания. Римский патриархат (Папство) занимался обустройством разрушенных ранее готами-арианами епархий в Италии и Испании, что не позволяло ему серьезно вмешиваться в административно-политические дела восточных провинций. Таким образом, после Пятого Вселенского Константинопольского Собора, созванного Юстинианом Великим в 553 г., только
Константинопольский патриархат был способен претендовать на расширение территориальной юрисдикции в восточном направлении, тем более что первый шаг к такому расширению Юстиниан Великий предпринял еще задолго до Вселенского Собора 553 г. Вся территория Лазики (современная Грузия) и большая часть Армении и Азербайджана (Кавказской Албании) в ходе боевых действий 556-561 гг. стали частями именно Константинопольского патриархата, а не территориально близкого Антиохийского патриархата [41, с. 276].

Согласно мирному договору между Восточной Римской империей и Эраншахром (562 г.) права ортодоксального Константинопольского патриархата становились признанными на всей территории Кавказа [29, с. 538-542]. В то же время Юстиниану удалось установить политическую власть ортодоксальной Христианской Церкви во всем регионе Причерноморья [42, с. 60-67]. С фракийских, крымских и грузинских берегов Понта Евксинского были изгнаны все организованные группы священников и монахов, открыто проповедующих монофизитство, арианство или несторианство. Весь регион Черного Моря, традиционно являвшегося внутренним морем Римской империи, прошел через тотальную христианскую ортодоксализацию [43, с. 78-84]. Права и политические привилегии Константинопольского патриархата в этом регионе должны были обозначать формирование дипломатического плацдарма для культурной экспансии официального Константинополя не столько вглубь «безнадежно варварских славянских племен» (сначала Юстиниан Великий, а позже и Юстин II официально передали их под власть Аварского каганата), сколько вглубь тюркоязычной евразийской степи.

Автор пропонуе читачам комплексний аналіз юридичної історії Тюркського каганату (552-603 рр.), 


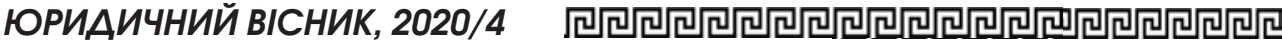

як за доби його становлення (545553 рр.), так $i$ в часи правління видатного полководия Муган-кагана (553-572 рр.). Встановлення тісних політико-правових зв'язків між тюрками $і$ Східною Римською імперією було наслідком укладення мирної угоди між візантійиями ma персами (562 р.). У 562, 563, 565 i 566 роках Тюркський каганат надсилав своїх офіційних послів y Константинополь. На той момент тюрки володіли юридичним статусом васалів китайського династичного царства Західна Вей (згідно з привілеєм 545 р.). Перемога над Жужаньським каганатом у 552 р. дозволила тюркам взяти під контроль усі тюрко-монгольські й маньчжурські племена східної частини Євразійського степу. У 554 р. тюрки почали боротьбу проти інших спадкоємиів племені хунну - «гуннів-ефталітів». Оскільки ефталіти вже тривалий час тероризували східні провіниії Новоперсидського царства, то іранський шахінщах («цар царів») Хосров Ануширван (531-579) прийняв рішення запросити частину тюркської орди на військову службу. При цььому ми припускаємо, щзо Хосров Ануширван, маючи великии uтат радників греко-римського походження, прагнув використати юридичну модель lex foedus, згідно з якою Римська імперія традиційно вербувала та приймала на імперську військову службу цуілі народи «варварів» (як германців чи слов'ян-землеробів, так і кочівників іранського, арабського чи гуннського походження). Задум був успішним. Муган-каган передав загони свого дядька Істемі («західну орду») під командування Хосрова, а донька Істемі стала дружиною персидського «иаря иарів». У 555-557 рр. тюрки розгромили останні прожужаньські сили в Північному Китаї (племена аварів) та підпорядкували своїй владі Хорезм. Внаслідок поразки частина аварів відступила аж у Волго-Донське міжріччя, де в 558 р. стала просити візантійського iмnератора Юстиніана Великого (527-565) надати їм статус федератів. Східна Римська імперія прийняла аварів у своє підданство $i$ де-юре заснувала Аварський каганат (558-805 рр.). Оскільки володіння Тюркського каганату тепер сягнули Волги, тюрки і перси уклали Договір про поділ ефталітських володінь (566 р.), що охоплювали межі сучасних Афганістану та Пакистану. Ратифікація нової угоди створила важливий прецедент в історико-правовому житті Євразіі. Тюркський каганат визнавав своїми сюзеренами як китайських імператорів із династї Західна Вей, так i шахіншаха Персї («прецедент полівасалітету»). При иььом тюрки надавали «сюзеренам» усі необхідні знаки уваги та визнання, вбачаючи в иьому простір для політичного маневрування, прагнучи повністю підпорядкувати своїи владі ключові відтинки Великого Шовкового Шляху. Прихід до влади у Візантії імператора Юстина II (565-578) ma подальша активізація торговельних контактів Константинополя з Тюркським каганатом привели до охолодження ірано-тюркських стосунків. У 567 р. Східна Римська імперія ініціювала переселення аварів у Паннонію та Дакію, тоді як Північне Причорномор'я передавалось західнотюркській орді Істемі на правах lех foedus. Oтне, станом на 568 р. Тюркський каганат юридично визнавав себе залежним від влади Східної Римської імперії, Ірану та Західної Вей, що, безумовно, мало призвести до вибуху чергового міжнародного збройного конфлікту.

Ключові слова: Великий Ель Тюркського народу (Тюркський каганат), Гектюрк-каган (правитель небесних тюрків), Аварський каганат, Новоперсидське царство (Ераншахр), Східна Римська імперія (Візантія). 
Melnyk V. Legal personality of the Turkic Khaganate (552568 ad): Iranian-Byzantine aspect The author offers readers a comprehensive analysis of the legal history of the Turkic Khaganate (552-603), both during its formation (545-553) and during the reign of the prominent military leader Muqan Qaghan (553-572). The establishment of close political and legal ties between the Turks and the Eastern Roman Empire was the result of a peace treaty between the Byzantines and the Persians (562). In 562, 563, 565 and 566, the Turkic Khaganate sent its official ambassadors to Constantinople. At that time, the Turks had the legal status of vassals of the Chinese dynastic kingdom of Western Wei (according to the privilege of 545). The victory over the Zhuzhan Khaganate in 552 allowed the Turks to take control of all the TurkoMongol and Manchurian tribes of the eastern part of the Eurasian steppe. In 554 , the Turks began to fight against other heirs of the Hun tribe - the "White Huns-Hephthalites". Since the Hephthalites had long terrorized the eastern provinces of the New Persian Empire, the Iranian shähanshāh (king of kings) Khosrow I Anushirvan (531579) decided to invite part of the Turkic horde to military service. At the same time, we assume that Khosrow Anushirvan, having a large staff of advisers of Greco-Roman origin, sought to use the lex foedus model, according to which the Roman Empire traditionally recruited and accepted "barbarians" for imperial military service. The idea was successful. Muqan Qaghan transferred the troops of his uncle Istami ("Western Horde") under the command of Khosrov, and Istami's daughter became the main wife of the Persian "king of kings". In 555-557, the Turks defeated the last pro-Zhuzhan forces in northern China (Avar tribes) and subjugated Khorezm. As a result of the defeat, some
Avars retreated as far as the VolgaDon interfluve, wherein they began to ask the Byzantine emperor Justinian the Great (527-565) to grant them the status of federates. The Eastern Roman Empire accepted the Avars as its citizens and, de jure, founded the Avar Khaganate (558-805). Since the possessions of the Turkic Khaganate now reached the Volga, the Turks and Persians concluded a treaty on the division of Hephthalite possessions (566), which covered the borders of modern Afghanistan and Pakistan. Ratification of the new agreement set an important precedent in the historical and legal life of Eurasia. The Turkic Khaganate recognized as its suzerains both the Chinese emperors of the Western Wei dynasty and the shähanshāh of Persia ("the precedent of polyvassality"). At the same time, the Turks gave the "suzerains" all the necessary signs of attention and recognition, seeing this as a space for political manoeuvring, seeking to completely subjugate the key sections of the Great Silk Road. The transfer of power in Byzantium to Emperor Justin II (565-578) and the further intensification of trade contacts between Constantinople and the Turkic Khaganate led to the cooling of Iranian-Turkic relations. In 567, the Eastern Roman Empire initiated the resettlement of the Avars in Pannonia and Dacia, while the Northern Black Sea Coast was ceded to the Western Turkic Horde by Istem as a lex foedus. Thus, as of 568, the Turkic Khaganate legally declared itself dependent on the authorities of the Eastern Roman Empire, Iran and the Western Wei, which, of course, should have led to the outbreak of another international armed conflict.

Key words: Great El of the Turkic people (Turkic Khaganate), Gцktbrks-kagan ("ruler of the celestial Turks"), Avar Khaganate, the Persian Empire (Ërānšahr), the Eastern Roman Empire (Byzantium). 


\section{Литература}

1.Гумилев Л.Н. Древние тюрки. Москва : Кльшников и Комаров и Ко., 1993. 536 с

2. Савинов Д.Г. Народы Южной Сибири в древнетюркскую эпоху. Ленинград : Изд-во ЛГУ, 1984. 174 с.

3. Бартольд В.В. Тюрки. Двенадцать лекций по истории Средней Азии. Москва : Юрайт, 2019. 154 с.

4. Гумилев Л.Н. В поисках вымышленного цзарства. Санкт-Петербург : Азбука-классика, 2014. 480 c.

5. Бартольд В.В. История культурной жизни Туркестана. Ленинград : Изд-во АН СССР, 1927. 256 c.

6. Кара-каган. Казахстан. Национальная энииклопедия / под ред. проф. Б.Г. Аягана. Aлматы : Главная редакция "Казак энииклопедиясы», 2005. T. 3. С. 143.

7. Kляиторный С.Г., Савинов Д.Г. Степные империи древней Евразии. Санкт-Петербург, 2005. 346 с.

8. Excerpta de legationibus. Pars II., Excerpta de legationibus gentium ad Romanos. Edidit Carolus de Boor. Berolini : Apud Weidmannos, 1903. P. 230-599.

9. Менандр Византиеи. История. Византийские историки: Дексипп, Эвнапий, Олимпиодор, Малх, Петр Магистр, Менандр, Кандид Исавр, Ноннос и Феофан Византиец / перевод Г.С. Дестуниса. Рязань : Александрия, 2003. C. 229-335.

10. Кузнецов В.А. Очерки истории алан. Пятигорск : Снег, 2016. 432 с.

11. Захарий Митиленский.

Сирийской хроники / перевод Н.В. Пигулевской. Вестник древней истории. 1939. № 1. C. 114-115.

12. Avenarius A. Die Awaren in Europa. Amsterdam ; Bratislava, 1974. 282 s.

13. Рашев Р. Прабългарите през V-VII век. София : Орбел, 2005. 348 c.

14. Божилов И., Димитров $X$ Protobulgarica (Заметки по истории протоболгар до серединь IX в.). Byzantinobulgarica. София, 1995. T. IX. C. 7-61.

15. Vernadsky G.V. Ancient Russia. New Haven: Yale University Press, 1943. 425 p.

16. Миринейский A. О царствовании Юстиниана / пер., ст. и примеч. М.В. Левченко. Москва ; Ленинград : Изд-во АН СССР, 1953. 221 с.

17. Чичуров И.С. Византийские исторические сочинения: «Хронография» Феофана, «Бревиарий» Никифора:
Тексты, перевод, комментарий ; отв. ред. В.Т. Пашуто. Москва: Наука, 1980. $216 \mathrm{c}$.

18. Серов В.В. Ранневизантийская дипломатия в 60-70-е гг. VI в. Известия Алтайского государственного универсиmema. 2009. № 4-1 (64). С. 195-201.

19. Феофилакт Симокатта. История / вступ. ст. Н.В. Пигулевской ; пер. С.П. Кондратьева. Москва : Арктос ; Buкa-npecc, 1996. 272 c.

20. Люттвак Эдвард H. Стратегия Византийской империи / пер. с англ. А.Н. Коваля. Москва : Русский фонд содействия образованию и науке, 2016. $664 \mathrm{c}$.

21. Митрофанов А.Ю. Аварский каганат как политический феномен языческого этно-религиозного контекста развития Христианской Ойкумены. Христианское чтение. 2016. № 6. C. 350-370.

22. Васильев А.А. История Византийской империи. Время до Крестовых походов (до 1081 г.). Санкт-Петербург : Алетейя, 1998. 514 c.

23. Мельник В.М. Византия, германиь и славяне у истоков международной правосубъектности государств: римское юридическое наследие и проблема исторического неравенства возможностей. Аннали юридичної історії. 2017. Том 1. № 2. C. 59-92.

24. Крадин Н.Н. Империя Хунну. Москва: Логос, 2001. 312 c.

25. Khazanov A.M. Nomads and the Outside World. 2nd Edition. University of Wisconsin Press, 1994. 442 p.

26. Мельник В.М. Вопрос об экономических контактах кочевников и земледельцев в истории древних хунну. Історія торгівлі, податків та мита : ХІІ Міжнародна наукова конферениія (25-26 жовтня 2018 р., Дніпро). Тези доповідей. Київ : Iнститут історії України НАНУ, 2018. С. 8-10.

27. Мурзин В.Ю. Скифская проблема глазами автора. Київ : Видавець Олег Філюк, 2014. 120 c.

28. Мухамадеев А.Р. Основы престолонаследия и династические браки в Жужаньском государстве. Народь и религии Евразии. Барнаул : Издательство Алтайского государственного универсuтema, 2020. Buın. 1 (22). C. 29-41.

29. Мищин Д.Е. Хосров I Ануширван (531-579), его эпоха и его жизнеописание и поучение в истории Мискавейха. 


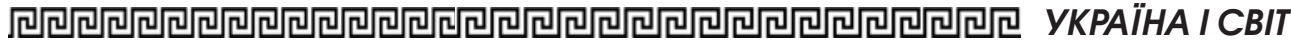

Москва : Институт востоковедения PAH, 2014. 696 c.

30. Жданович О.П. Посольство Земарха в ставку тюркского кагана (перевод и комментарии фрагментов труда Менандра Протектора). Золотоордынское обозрение. 2014. № 2 (4). С. 6-20.

31. Диль Ш. Юстиниан и византийская изивлизация в VI веке. Санкт-Петербург : Типография Альтшулера, 1908. $X X X I V+687 c$

32. Аюбов А.P. Особенности эволюиии согдо-тюркских взаимоотношений в раннем средневековье. Вестник Таджикского государственного университета права, бизнеса и политики. Серия гуманитарных наук. 2017. № 1 (70). C. 27-35.

33. Мельник В. Кінеиь античності: як $і$ коли слов'яни вийщли на світову арену міжнародних відносин? Всесвіт : незалежний літературно-мистеиький та громадсько-політичний журнал. 2019. №.№ 9-12. С. 203-208.

34. Пигулевская Н.В. Византийская дипломатияиторговляшелком. Византийский временник. 1947. T. 1 (XXVI). С. 184-214.

35. Пигулевская Н.В. Византия на путях в Индию. Москва : АН СССР, 1951. 170 с.

36. Дюличев В.П. Крым. История в очерках. Симферополь : Рубин, 2008. 496 с.

37. Жданович О.П. Менандр Протектор. История: О посольствах тюрков к персам и византийцам в 568 году (перевод и комментарии). Золотоордынское обозрение. 2014. № 1 (3). С. 22-32.

38. Хизер П. Восстановление Римской uмперии. Реформаторь Церкви и претенденты на власть. Москва : Центрполиграф, 2015. 576 c.

39. Курбатов Г.Л. Ранневизантийские nортреть: $K$ истории общественно-политической мьсли. Ленинград : Издательство Ленинградского университета, 1991. $272 \mathrm{c}$.

40. Дворкин А. Очерки по истории вселенской православной иеркви. Нижний Новгород : Христианская библиотека, 2016. $1024 \mathrm{c}$.

41. Allen W.E.D. A History of the Georgian People. From the beginning down to the Russian Conquest in the Nineteenth Century. London: Kegan Paul, Trench Trubner \& Company Limited, 1932. XXIV+429p.

42. Уманеи А.Н., Шевченко Ю.А. Появление раннего христианства III-VII вв. в Северном Причерноморье. Сіверщина в історії Украӥни : Збірник наукових праць. Київ, 2010. Випуск 3. С. 60-67.

43. Шевченко Ю.Ю., Уманец А.Н. О времени учреждения и существования Готской митрополии. Сіверщина в історії України : збірник наукових праиь. Kü̈в, 2011. Bun. 4. C. 78-84. 